\title{
Bearing Capacity Effect of Soft Clay with Sand Compaction Piles
}

\author{
Teena George ${ }^{1}$, Hari .G ${ }^{2}$
}

\begin{abstract}
An expansive soil is to be source of trouble to civil engineering as its strength, volume and compressibility changes tremendously on wetting. Sand compaction piles are one of the most widely used ground improvement techniques in case of soft clays. They increase the bearing capacity and reduce the settlements of soft clays. This paper is an attempt to investigate the load carrying capacity of soft clay with and without sand compaction piles through laboratory model tests conducted on single and group sand compaction piles by varying diameter, length and spacing of sand compaction piles.
\end{abstract}

Keywords: Sand compaction piles, expansive soil, bearing capacity, undrained shear strength, stone columns

\section{Introduction}

Expansive soil becomes soft on wetting and strength loses results in differential settlement. Hence such soil is avoided, replaced with good soil and soil improving techniques are also adopted in such soils. Vast areas, particularly among coast are covered with thick soft clay deposits having very low shear strength and high compressibility. In view of increasing developments on coastal areas in recent past, a number of ports, industries and other infrastructure facilities are being built. Although use of pile foundations can meet all the design requirements, negative drag force and the large length of the pile often results in prohibitive costs. On the other hand, ground improvement techniques are normally preferred for economical considerations, one of which is the sand compaction pile (SCP) method.

Studies show that in soft marine clays, construction of sand compaction piles have proved to be successfully established. The method of sand compaction pile improves weak soil stratums by introducing a number of well-compacted and large-diameter sand columns into soil. The load carrying capacity of the ground increases and settlement decreases significantly and the ground become useable to support the structure. The presence of compaction piles creates a composite material which is stiffer and stronger than the original soil.

Sankar.K And Shroff.A.V (1997), conducted experimental studies to study the effect of pattern of installation of stone columns and showed that triangular pattern seems to be optimum and rational.

A.P.Ambily and S.R.Gandhi (2004), studied on the behaviour of clay reinforced with stone columns. The load test was conducted by varying spacing of stone column. The test result indicates that the load settlement for s/d of 2 and 3 gives significant improvement than s/d of 4 .

S.Murugesan And K.Rajagopal (2007), investigated the improvement of load capacity of stone columns with and without encasement. The results from the load tests indicated a clear improvement in the load capacity of stone column due to encasement.
K. V. Sudheer, Arvee Sujil Johnson And N. Unnikrishnan (2011), conducted experimental study on behaviour of a compaction sand pile and a stone column in a soil sample of fine sand containing various percentages of clay. Results concluded that even with small percentage of clay present in the loose fine sand sample, ground improvement by stone column is highly preferable than compaction sand pile.

Rakesh Kumar and P.K. Jain (2013), investigated the improvement of load carrying capacity of granular pile with and without geogrid encasement through laboratory model tests conducted on single granular pile installed in expansive clay bed prepared in controlled condition in small testing tanks. The results from the load tests indicated a clear improvement in the load carrying capacity of clay, with granular pile and with encased granular pile. The increase in the load carrying capacity also increases as the diameter of the granular pile increases.

The present study has been carried out to determine the improvement behaviour of soft clay reinforced with sand compaction piles of varying diameter, length and spacing.

\section{Experimental Program}

The experimental study was carried out with the objective to estimate the load carrying capacity of single and group sand compaction piles.

Two types of tests were carried out in a test tank with a single compaction pile and group compaction piles assuming triangular pattern of installation. The test program is as shown in Table 1. Each test was repeated 2 times to obtain an average result. A total of 16 tests were performed.

Table 1: Experimental Program

\begin{tabular}{|c|c|c|}
\hline \multicolumn{3}{|c|}{ Single SCP } \\
\hline Diameter $(\mathrm{mm})$ & \multicolumn{2}{|c|}{ Length of SCP $(\mathrm{mm})$} \\
\hline 90 & 150 & 300 \\
\hline 110 & 150 & 300 \\
\hline \multicolumn{3}{|c|}{ Group SCP } \\
\hline Diameter $(\mathrm{mm})$ & \multicolumn{2}{|c|}{ Spacing of SCP $(\mathrm{mm})$} \\
\hline 8 & 24 & 32 \\
\hline 12 & 36 & 48 \\
\hline
\end{tabular}




\section{International Journal of Science and Research (IJSR) \\ ISSN (Online): 2319-7064 \\ Index Copernicus Value (2013): 6.14 | Impact Factor (2015): 6.391}

\section{A. Experimental set up}

The tests were conducted in a tank of dimension 300mmx $300 \mathrm{~mm} \times 300 \mathrm{~mm}$. The dimension was taken such that the zone of influence of compaction pile is within the tank.

\section{B. Properties of materials used}

Two basic materials used for this study were clay representing the soft soil to be improved and sand, the pile forming material. The properties of each of these are as follows:

\section{Expansive Clay}

The clay used was from the upper Kuttanad area. The soil was air dried, pulverized and passed through $0.075 \mathrm{~mm}$ sieve. Properties of clay are listed in Table II.

Table 2: Properties of Expansive Soil

\begin{tabular}{|l|l|}
\hline Properties & Value \\
\hline Type of clay & $\mathrm{CH}$ \\
\hline Specific Gravity & 2.07 \\
\hline Liquid Limit (\%) & 160 \\
\hline Plastic Limit (\%) & 113 \\
\hline Plasticity Index (\%) & 47 \\
\hline Clay Content (\%) & 61 \\
\hline Silt Content (\%) & 39 \\
\hline Modulus of Elasticity (kPa) & 1500 \\
\hline Initial Water Content (\%) & 130 \\
\hline Field Density (kN/m $\left.{ }^{3}\right)$ & 13.19 \\
\hline Undrained Shear Strength $\left(\mathrm{kN} / \mathrm{m}^{2}\right)$ & 8 \\
\hline
\end{tabular}

2. Sand

Properties of sand are listed in Table III. The shear strength parameters of sand were determined from direct shear tests in small shear box with pan dimensions of $60 \mathrm{~mm} \times 60 \mathrm{~mm}$ and height of $25 \mathrm{~mm}$.

Table 3: Properties of Sand

\begin{tabular}{|l|l|}
\hline \multicolumn{1}{|c|}{ Properties } & \multicolumn{1}{c|}{ Value } \\
\hline Type of sand & $\mathrm{GW}$ \\
\hline Specific Gravity & 2.68 \\
\hline Field Density $\left(\mathrm{kN} / \mathrm{m}^{3}\right)$ & 15.09 \\
\hline Saturated Density $\left(\mathrm{kN} / \mathrm{m}^{3}\right)$ & 18.69 \\
\hline $\mathrm{D}_{10}(\mathrm{~mm})$ & 0.425 \\
\hline $\mathrm{D}_{30}(\mathrm{~mm})$ & 1.18 \\
\hline $\mathrm{D}_{60}(\mathrm{~mm})$ & 2.36 \\
\hline $\mathrm{C}_{\mathrm{u}}$ & 5.55 \\
\hline $\mathrm{C}_{\mathrm{c}}$ & 1.39 \\
\hline Modulus of Elasticity $(\mathrm{kPa})$ & 5000 \\
\hline Angle of Internal Friction $\left(^{\circ}\right)$ & 27 \\
\hline
\end{tabular}

\section{Preparation of soft clay bed}

The clay bed for the tests was prepared in a tank of plan dimensions $300 \mathrm{~mm} \times 300 \mathrm{~mm}$ and $300 \mathrm{~mm}$ depth at its field density. The soft clay bed was prepared by pouring the clay in layers. A thin coat of grease was applied along the inner surface of the tank wall to reduce friction between clay and tank wall. Clay was thoroughly mixed and filled in the tank in layers by hand with measured quantity by weight. The surface of each layer was provided with a uniform compaction with a tamper to achieve the field density.

Care was taken to ensure that no significant air voids were formed in the test bed. For every load test, the clay bed was prepared afresh in the tank by this method and the sand compaction piles were installed in it. This method was carefully followed to maintain uniformity of clay bed properties between successive load tests.

\section{Construction of sand compaction pile}

All the load tests were conducted on the sand compaction piles installed at the centre of the clay bed prepared in the test tank. The plan area of the tank is so selected that the loading on the sand compaction piles would not be affected by the tank boundaries. The compaction piles were installed by displacement method and were extended down to the required depth of the tank.

A casing pipe having an outer diameter equal to the diameter of the compaction pile was used to install the compaction piles. The casing pipe was pushed into the soil till the bottom of the tank along with a base plate in order to prevent the soil from entering into the casing pipe. When the casing pipe is pulled out, the base plate remains in the soil. Only static force was manually applied to push the casing pipe gently into the soil so as to minimize the disturbance in the clay soil that may change the properties of the clay after reinforcement. Outer surface of the pipe was lubricated by applying a thin layer of grease for easy withdrawal without any significant disturbance to the surrounding soil. The displaced clay during the installation of compaction piles was taken out and the surface of the soil was trimmed level.

The quantity of sand required to form the sand pile was premeasured and charged into the casing pipe in layers of $50 \mathrm{~mm}$ thickness. Each layer was compacted to achieve uniform field density. The pipe was then raised in stages ensuring a minimum of $5 \mathrm{~mm}$ penetration below the top level of the placed material. The procedure was repeated until the compaction pile was compacted to the required height.

\section{E. Test procedure}

After preparing the compaction piles, the load deformation behaviour of the column treated soil was studied by applying vertical load in a loading frame. The loading plate used in these tests were circular, having diameter of $100 \mathrm{~mm}$. The load was applied through a proving ring with a constant displacement rate of $1.25 \mathrm{~mm} / \mathrm{min}$. The loads corresponding to different displacements were measured through a precaliberated proving ring. The settlement readings up to $25 \mathrm{~mm}$ were recorded. As the loading is quick, it is essentially undrained loading which simulates the loading condition immediately after the construction.

\section{Results and Discussions}

The load - settlement curves obtained from the load tests on clay bed without and with sand compaction piles of varying lengths, diameters and spacings are shown in Fig 1,2,3 and 4. It may be noted from these figures that inclusion of compaction piles in the soft expansive soil increases the load carrying capacity of the soil. 


\section{International Journal of Science and Research (IJSR)

a) Single column

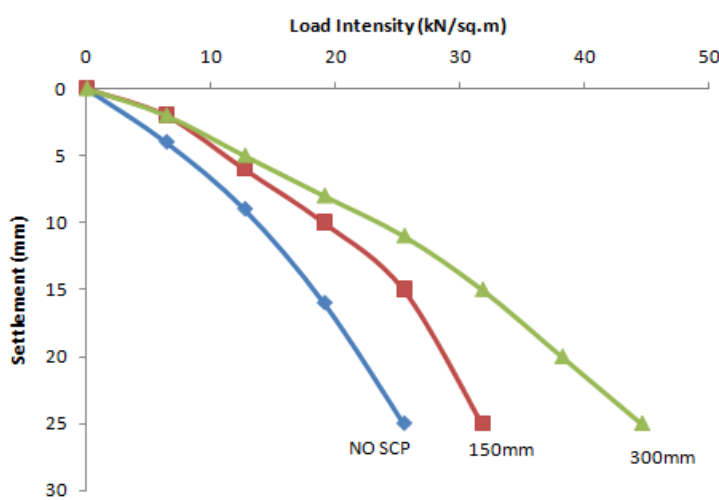

Figure 1: Load-Settlement Curve for 90mm Diameter Sand Compaction Pile of Varying Depth 150mm and 300mm

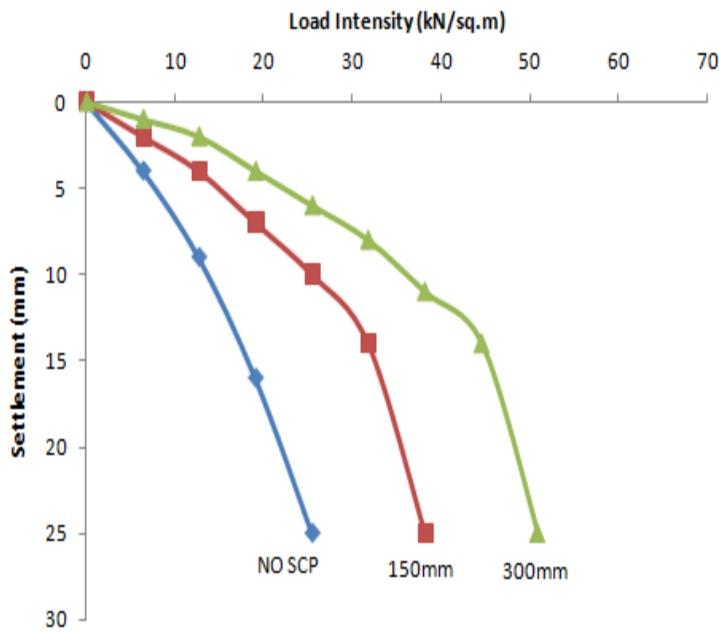

Figure 2: Load-Settlement Curve for 110mm Diameter Sand Compaction Pile of Varying Depth 150mm and 300mm

\section{b) Group column}

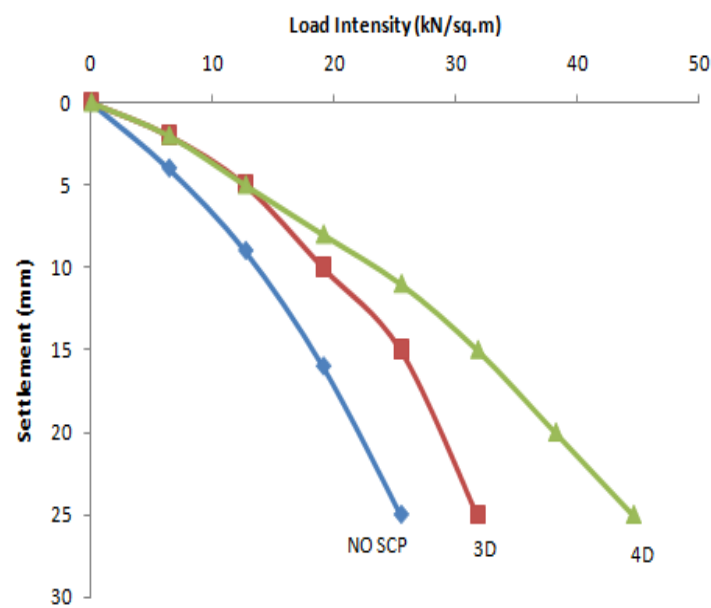

Figure 3: Load-Settlement Curve for 8mm Diameter Sand Compaction Pile of Varying Spacing 3D and 4D

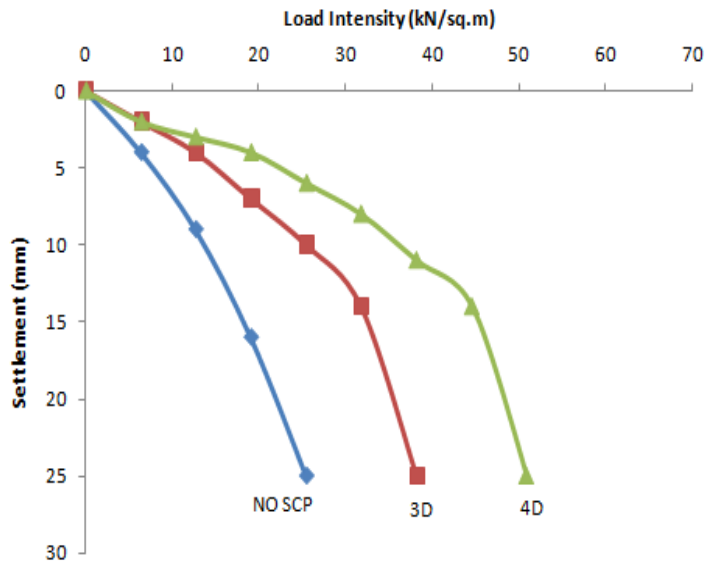

Figure 4: Load-Settlement Curve for 12mm Diameter Sand Compaction Pile of Varying Spacing 3D and 4D

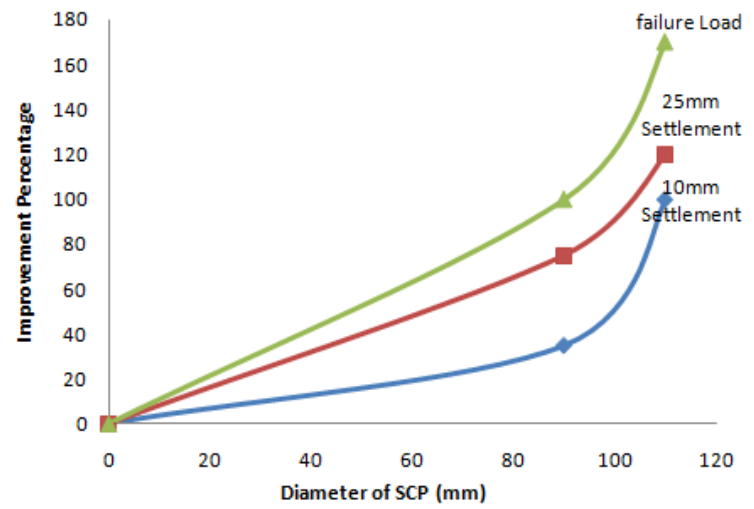

Figure 5: Behaviour of Improvement Percentage by Single Piles

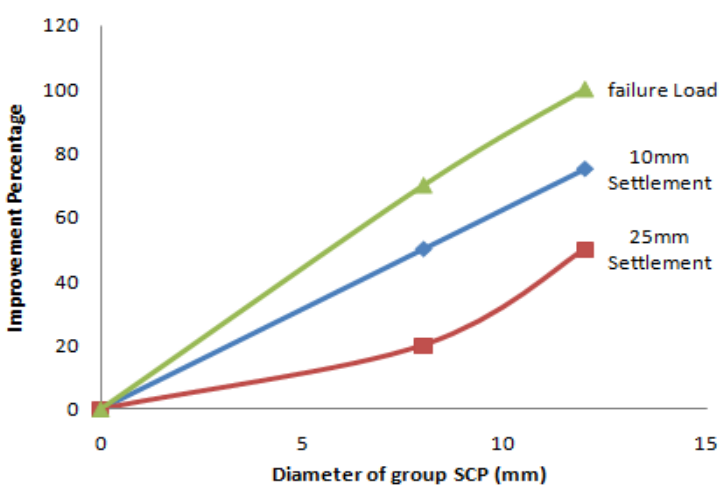

Figure 6: Behaviour of Improvement Percentage by Group Piles

From the test results it was clear that the improvement percentage of soil due to insertion of sand compaction piles is increased upto $100 \%$ for $25 \mathrm{~mm}$ settlement.

\section{Conclusions}

The results of the testing program give important insight in to the performance of sand compaction piles in expansive clay. The trends obtained in these laboratory tests are in good agreement with the results reported in the literature. The major conclusions that can be drawn from the present study are as follows:

1) Inclusion of sand compaction pile considerably improves the load-settlement characteristics of expansive clay. The ultimate load of clay bed reinforced with SCP is 


\section{International Journal of Science and Research (IJSR) \\ ISSN (Online): 2319-7064}

Index Copernicus Value (2013): 6.14 | Impact Factor (2015): 6.391

increased about 1.5 times the ultimate load in plane clay bed.

2) The load capacity increases as the diameter of the Sand compaction pile increases.

\section{References}

[1] Sankar .K and Shroff .A.V (1997), "Experimental Study on Floated Stone Column in Soft Kaolinite Clay". Proc. of Indian Geotechnical Conference 265-268.

[2] Ambily, A.P, and Gandhi, S.R (2004) "Experimental and theoretical evaluation of stone column in soft clay". ICGCE - 2004.

[3] S.Murugesan and K.Rajagopal (2010)," Studies on the Behaviour of Single and Group of Geosynthetic Encased Stone Columns". Jl. Geotech Geoenv Engineering, 136(1).

[4] K.V.Sudheer, Arvee Sujil Johnson and N. Unnikrishnan (2011) "Behaviour of compaction sand pile and stone column in fine sand with clay". Indian Geotechnical Conference - 2011, pp 15- 17.

[5] Rakesh Kumar and P.K.Jain (2013), "Expansive soil reinforcement by geogrid encased granular pile". International Journal on Emerging Technologies 4(1); 55-61 (2013). 